\title{
Rethoracotomy for early complications: A marker for increased morbidity and mortality
}

\author{
Erken komplikasyonlar nedeniyle retorakotomi: Artmış morbidite ve mortalite için bir işaret
}

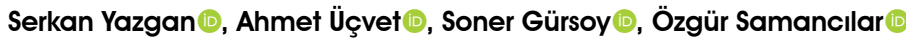

Department of Thoracic Surgery, University of Health Sciences, Dr. Suat Seren Chest Diseases and Surgery Training and Research Hospital, izmir, Turkey

\begin{abstract}
Background: This study aims to examine the indications, timing and risk factors of rethoracotomy, analyze the postoperative results, and give suggestions to reduce the risks.

Methods: A total of 3,292 patients operated via thoracotomy between January 2006 and January 2017 were evaluated retrospectively. Demographic data, initial operative indications, surgical procedures, indications for rethoracotomy and preoperative risk factors, intraoperative findings and surgical methods, timing of rethoracotomy, morbidity and mortality results were analyzed of 66 patients (60 males, 6 females; mean age $59.4 \pm 12.4$ years; range, 17 to 80 years) who were performed rethoracotomy before being discharged. Rethoracotomies performed within 72 hours after the first operation constituted the early and those performed after 72 hours constituted the late rethoracotomy group.
\end{abstract}

Results: Rethoracotomy was performed in average 4.7 days (range, 1 to 17 days). Early rethoracotomy was performed on 42 patients $(1.3 \%)$ and $38(90.4 \%)$ of these were due to hemorrhage. The most frequent indication for rethoracotomy was hemorrhage $(n=41,1.2 \%)$, followed by bronchopleural fistula $(n=17,0.5 \%)$. The other indications were chylothorax, lobe torsion, parenchymal air leak and collapse, and diaphragmatic laceration. Eight patients had rib fractures and all of these patients were over the age of 60. Eight patients who were performed rethoracotomy due to hemorrhage were using antiaggregant drugs. The postoperative morbidity and mortality rates were $33.3 \%(n=22)$ and $24.2 \%(n=16)$, respectively.

Conclusion: Rethoracotomy still has high morbidity and mortality rates. The main cause of rethoracotomy performed due to hemorrhage may be rib fractures or antiaggregant drugs. The most remarkable indications of rethoracotomy are hemorrhage and bronchopleural fistula.

Keywords: Bronchopleural fistula; hemorrhage; morbidity; mortality; rethoracotomy.

\section{$\ddot{O} Z$}

Amaç: $\mathrm{Bu}$ çalışmada, retorakotominin endikasyonları, zamanlaması ve risk faktörleri incelendi, ameliyat sonrası sonuçlar analiz edildi ve risklerin azaltılması için önerilerde bulunuldu.

Çalışma planı: Ocak 2006 - Ocak 2017 tarihleri arasında torakotomi yolu ile ameliyat edilen toplam 3292 hasta retrospektif olarak değerlendirildi. Taburcu edilmeden önce retorakotomi yapılmış 66 hastanın (60 erkek, 6 kadın; ort. yaş 59.4 \pm 12.4 yıl; dağılım, 17-80 yıl) demografik verileri, ilk ameliyat endikasyonları, cerrahi prosedürleri, retorakotomi endikasyonları ve ameliyat öncesi risk faktörleri, ameliyat sırası bulgular ve cerrahi yöntemler, retorakotomi zamanlaması, morbidite ve mortalite sonuçları analiz edildi. İlk ameliyattan sonra 72 saat içinde yapılan retorakotomiler erken ve 72 saatten sonra yapılanlar geç retorakotomi grubunu oluşturdu.

Bulgular: Retorakotomi ortalama 4.7 günde (dağılım, 1-17 gün) yapıld. Erken retorakotomi 42 hastada (\%1.3) yapıldı ve bunların 38'i (\%90.4) kanamadan dolayı idi. Retorakotominin en sık endikasyonu kanamayd $1(n=41, \% 1.2)$ ve bunu bronkoplevral fistül takip etti $(n=17, \% 0.5)$. Diğer endikasyonlar; şilotoraks, lob torsiyonu, parankimal hava kaçağı ve kollaps ve diafragmatik laserasyon idi. Sekiz hastada kaburga kırı ğ1 vardı ve bu hastaların hepsi 60 yaş üstü idi. Kanamadan dolayı retorakotomi yapılan sekiz hasta, antiagregan ilaç kullanıyordu. Ameliyat sonrası morbidite ve mortalite sirasıly \%33.3 (n=22) ve $\% 24.2(\mathrm{n}=16)$ idi.

Sonuç: Retorakotomi hala yüksek morbidite ve mortalite oranlarına sahiptir. Kaburga kırıkları veya antiagregan ilaçlar, kanama nedeni ile yapılan retorakotominin ana nedeni olabilir. Retorakotominin en dikkat çekici endikasyonları kanama ve bronkoplevral fistüldür.

Anahtar sözcükler: Bronkoplevral fistül; kanama; morbidite; mortalite; retorakotomi.

Received: July 26, 2017 Accepted: January 16, 2018

Correspondence: Serkan Yazgan, MD. Sağlık Bilimleri Üniversitesi, Dr. Suat Seren Göğüs Hastalıkları ve Cerrahisi Eğitim ve Araştırma Hastanesi Göğüs Cerrahisi Kliniği, 35170 Konak, Izmir, Turkey. Tel: +90 232 - 4333333 e-mail: serkanyazgan@gmail.com 
There are various indications of rethoracotomy following thoracic surgery. The time of rethoracotomy might vary for each indication. While early rethoracotomy within hours is obligatory for hemorrhage and lobar torsion, rethoracotomy should be considered for chylothorax after 10 to 14 days of conservative treatment. It can be lifesaving, but it might also increase morbidity and mortality. Rethoracotomy after surgery for malignant disease is riskier for those patients who are generally old, have comorbidities and are in a bad condition for a second surgical intervention. It is therefore challenging for the surgeon to determine the right indication and the timing of the procedure. The incidence of rethoracotomy is approximately $1-4.6 \% .^{[1-8]}$ Current studies do not report a remarkable decrease in the rate of early rethoracotomy after thoracotomy. However, depending on improvements of surgical techniques and equipment in the last decade, with the increase of minimally invasive methods, there is a slight decrease in rethoracotomy and postoperative mortality rates when all procedures are considered together. To reduce the need for rethoracotomy, the patients at risk should be identified preoperatively and the precautions should be taken. In this study, we aimed to examine the indications, timing and risk factors of rethoracotomy, analyze the postoperative results, and give suggestions to reduce the risks.

\section{PATIENTS AND METHODS}

A total of 3,292 patients operated via thoracotomy at University of Health Sciences, Dr. Suat Seren Chest Diseases and Surgery Training and Research Hospital between January 2006 and January 2017 were analyzed retrospectively. A posterolateral thoracotomy performed by preserving serratus anterior muscle was used as the standard method of thoracotomy. The study was conducted in accordance with the principles of the Declaration of Helsinki.

Data were collected from hospital database, operational reports, patient charts and national mortality database. A total of 66 patients (60 males, 6 females; mean age 59.4 \pm 12.4 years; range, 17 to 80 years) who underwent rethoracotomy before being discharged were identified. The period between primary operation and rethoracotomy related to indication were noted. The patients on whom rethoracotomy was performed within the first 72 hours were classified as the early rethoracotomy group and the others were classified as the late rethoracotomy group. The earliest rethoracotomy was performed at the $20^{\text {th }}$ minute and the latest was performed on the $17^{\text {th }}$ day. Patients who underwent rethoracotomy after discharge due to elective causes were excluded from the study.

The use of antiaggregant or anticoagulant agents, neoadjuvant chemotherapy and/or radiotherapy, diabetes mellitus, history of tuberculosis, age and smoking were regarded as predisposing factors for rethoracotomy. In addition, bronchial closure methods and type of resection were analyzed as risk factors of bronchopleural fistula (BPF). Postoperative deaths within 30 days were recorded as death due to operation. Prolonged air leak, pneumonia, atelectasis, insufficient pulmonary expansion of the remaining lung, dyspnea, surgical wound infection, empyema, BPF and hemorrhage despite rethoracotomy were recorded as postoperative morbidity. Patients aged 60 and older, and under the age of 60 were evaluated in two different groups for risk assessment in terms of rethoracotomy.

Coagulation parameters in blood samples and platelet levels of all patients were checked during preoperative preparation. Antiaggregant or anticoagulant use on the patients was stopped at least five days before the operation, and the patients were followed-up and operated with low molecular weight heparin if there was an absolute indication. Bloody drainage over $1000 \mathrm{~mL}$ within one hour or over $200 \mathrm{~mL}$ per hour for the first four hours from chest tube was regarded as surgical bleeding requiring rethoracotomy.

Bronchopleural fistula was suspected due to decreased fluid level or air-fluid level in the chest $\mathrm{X}$-ray, lung collapse, massive air leak, abundant and bloody expectoration and confirmed by fiberoptic bronchoscopy.

\section{Statistical analysis}

Excel software (Microsoft Corp., Seattle, WA, USA) was used to analyze the data. The means and standard deviations of the continuous variables, and number and percent of categorical variables were given by using descriptive statistics.

\section{RESULTS}

During the 11-year study period, of 3,292 patients who were operated via thoracotomy, 66 patients (2\%) required rethoracotomy due to early surgical complications. Early rethoracotomy was performed on 42 patients $(1.3 \%)$ and $38(90.4 \%)$ of those were due to hemorrhage. The mean time between the first and second operations in early rethoracotomies was $29.03 \pm 23.48$ hours. The clinicopathological characteristics of the patients and mortality rates are shown in Table 1. 
Table 1. Characteristics of patients and mortality rates

\begin{tabular}{|c|c|c|c|c|c|c|c|c|c|c|c|c|c|c|}
\hline & \multicolumn{2}{|c|}{ Total } & \multicolumn{2}{|c|}{ Early $\mathrm{RT}^{*}$} & \multicolumn{2}{|c|}{ Late RT* } & \multicolumn{2}{|c|}{ Hemorrhage } & \multicolumn{2}{|c|}{$\mathrm{BPF}^{*}$} & \multicolumn{2}{|c|}{ Other RT } & \multicolumn{2}{|c|}{ Mortality } \\
\hline & $\mathrm{n}$ & $\%$ & $\mathrm{n}$ & $\%$ & $\mathrm{n}$ & $\%$ & $\mathrm{n}$ & $\%$ & $\mathrm{n}$ & $\%$ & $\mathrm{n}$ & $\%$ & $\mathrm{n}$ & $\%$ \\
\hline Total & 66 & 100 & 42 & 63.6 & 24 & 36.4 & 41 & 62.1 & 17 & 25.8 & 8 & 12.1 & 16 & 24.2 \\
\hline \multicolumn{15}{|l|}{ Age (year) } \\
\hline$<60$ & 33 & 50 & 20 & 47.6 & 13 & 54.2 & 19 & 46.3 & 9 & 52.9 & 5 & 62.5 & 6 & 37.5 \\
\hline$\geq 60$ & 33 & 50 & 22 & 52.3 & 11 & 45.8 & 22 & 53.7 & 8 & 47.1 & 3 & 37.5 & 10 & 62.5 \\
\hline \multicolumn{15}{|l|}{ Gender } \\
\hline Male & 60 & 90.9 & 38 & 90.5 & 22 & 91.7 & 37 & 90.2 & 16 & 94.1 & 7 & 87.5 & 14 & 87.5 \\
\hline Female & 6 & 9.1 & 4 & 9.5 & 2 & 8.3 & 4 & 9.8 & 1 & 5.9 & 1 & 12.5 & 2 & 12.5 \\
\hline \multicolumn{15}{|c|}{ Smoking history } \\
\hline Yes & 55 & 83.3 & 35 & 83.3 & 20 & 83.3 & 33 & 80.5 & 16 & 94.1 & 6 & 75 & 14 & 87.5 \\
\hline No & 11 & 16.7 & 7 & 16.7 & 4 & 16.7 & 8 & 19.5 & 1 & 5.9 & 2 & 25 & 2 & 12.5 \\
\hline \multicolumn{15}{|c|}{ Preoperative risk* } \\
\hline Present & 32 & 48.5 & 22 & 52.4 & 10 & 41.7 & 23 & 56.1 & 7 & 41.2 & 2 & 25 & 10 & 62.5 \\
\hline Absent & 34 & 51.5 & 20 & 47.6 & 14 & 58.3 & 18 & 43.9 & 10 & 58.8 & 6 & 75 & 6 & 37.5 \\
\hline
\end{tabular}

RT: Rethoracotomy; BPF: Bronchopleural fistula; * Preoperative risk: Neoadjuvant treatment, diabetes mellitus, previous tuberculosis, antiaggregant treatment.

Rethoracotomy was performed in 4.7 days (range, 1-17 days) on average. While the most common cause of early rethoracotomy was hemorrhage or clotted hemothorax, it was BPF for late rethoracotomy. When all thoracotomies were considered, the most common indication for rethoracotomy was hemorrhage as it was seen in 41 patients $(1.2 \%)$, followed by BPF in 17 patients $(0.5 \%)$. The indications for rethoracotomy are listed in Table 2.

According to initial surgical indications, operation was performed on 53 patients for malignant disease and 13 patients for benign pathologies. Eleven patients (20.7\%) with malignancy received neoadjuvant therapy. Initial indications of surgery and operations performed are listed in Table 3. While the most common site of hemorrhage was the chest wall being seen in 41 patients $(1.2 \%)$, no particular focus of bleeding was found in the majority of the patients $(\mathrm{n}=15,35.7 \%)$. During thoracotomy, rib fracture was detected in five of 15 patients who did not have any site of hemorrhage, and in a patient who had bleeding from intercostal artery. The causes of hemorrhage are shown in Table 4. Eight $(19.5 \%)$ of 41 patients whom rethoracotomy was performed on due to hemorrhage were using antiaggregant drugs. When other predisposing factors were also considered, a total of 23 patients (23/41) had preoperative risk factors. Postoperative mortality was detected in seven patients who underwent rethoracotomy due to

Table 2. Indications for rethoracotomy

\begin{tabular}{|c|c|c|c|c|c|c|}
\hline & \multicolumn{2}{|c|}{$\begin{array}{l}\text { Number and rate of early } \\
\text { rethoracotomy }\end{array}$} & \multicolumn{2}{|c|}{$\begin{array}{l}\text { Number and rate of late } \\
\text { rethoracotomy }\end{array}$} & \multicolumn{2}{|c|}{ Total number and rate } \\
\hline & $\mathrm{n}$ & $\%$ & $\mathrm{n}$ & $\%$ & $\mathrm{n}$ & $\%$ \\
\hline Hemorrhage/clotted hemothorax & 38 & 58 & 3 & 4 & 41 & 62 \\
\hline Bronchopleural fistula & 2 & 3 & 15 & 23 & 17 & 26 \\
\hline Parenchymal air leak & 1 & 1.5 & 3 & 4.5 & 4 & 6 \\
\hline $\begin{array}{l}\text { Deep thoracotomy wound infection and } \\
\text { separation }\end{array}$ & - & - & 1 & 1.5 & 1 & 1.5 \\
\hline Lobe torsion & 1 & 1.5 & - & - & 1 & 1.5 \\
\hline Chylous leak & - & - & 1 & 1.5 & 1 & 1.5 \\
\hline Diaphragmatic rupture & - & - & 1 & 1.5 & 1 & 1.5 \\
\hline
\end{tabular}


Table 3. Initial operative diagnoses of patients and applied surgical methods $(n=66)$

\begin{tabular}{lcclc}
\hline Initial operative indication & $\mathrm{n}$ & $\%$ & Applied surgical methods & $\mathrm{n}$ \\
\hline Non-small cell lung cancer & 52 & 78.8 & Pneumonectomy & 18 \\
& & & Bilobectomy & 2 \\
& & & Lobectomy & 26 \\
& & & Sleeve resections & 5 \\
& & & Wedge resection & 1 \\
Congenital diseases & 3 & 4.5 & Mediastinal cyst excision & 1 \\
& & & Diaphragm surgery & 2 \\
Recurrent pneumothorax & 2 & 3 & Apical bullae-bleb resection, apical pleurectomy & 2 \\
Giant bullae & 2 & 3 & Bullae resection, apical pleurectomy & 2 \\
Injuries penetrating thorax & 2 & 3 & Repair of parenchyma, wedge & 2 \\
Malignant thymoma & 1 & 1.5 & Extended thymectomy, decortication, wedge & 1 \\
Cyst hydatid & 1 & 1.5 & Cystotomy, capitonnage & 1 \\
Tuberculous cavity and aspergilloma & 1 & 1.5 & Bilobectomy & 1 \\
Bronchiectasis & 1 & 1.5 & Lobectomy & 1 \\
Pachypleuritis & 1 & 1.5 & Decortication & 1 \\
\hline
\end{tabular}

hemorrhage (17.1\%). The postoperative morbidity rate was $39 \%(16 / 41)$.

Bronchopleural fistula was detected in 17 patients who required rethoracotomy. Bronchopleural fistula was most frequently detected in right sided procedures with a rate of $76.4 \%$ (13/17). Bronchopleural fistula was most frequently seen after pneumonectomy and seven of the eight pneumonectomy patients with BPF were right pneumonectomies. Of the 17 patients, only two had early rethoracotomy. According to the analysis of predisposing factors for BPF, 58.8\% (10/17) of the patients had neoadjuvant therapy, diabetes, or previous history of tuberculosis. Bronchial stumps of seven patients were closed manually and 10 patients' stumps were closed using bronchial staplers. Four patients required further resection.

Table 4. Causes of hemorrhage

\begin{tabular}{lcc}
\hline Source of hemorrhage & $\mathrm{n}$ & $\%$ \\
\hline Thoracic wall & 10 & 24.4 \\
Mediastinal adipose tissue & 5 & 12.2 \\
Intercostal artery & 4 & 9.8 \\
Pulmonary artery stump & 3 & 7.3 \\
Lung parenchyma & 3 & 7.3 \\
Vena azygos & 1 & 2.4 \\
Unidentified focus & 15 & 36.6 \\
\hline
\end{tabular}

Two of these patients underwent middle lobectomy and bronchial sleeve resection and two patients underwent completion pneumonectomy. Two patients who underwent completion pneumonectomy and one patient who underwent bronchial sleeve resection along with middle lobectomy ended up with postoperative mortality. On the other 13 patients, either only stump revision was performed or additional procedures were applied to stump with intercostal muscle flap and autologous fibrin glue. In seven (41.2\%) of these patients, rethoracotomy eventuated with postoperative mortality. In two of these patients, massive hemoptysis was the cause of death and in five patients, recurred fistula and respiratory failure resulted in mortality. While the BPF was closed without any problems in six of the other 10 patients and they were discharged, BPF reoccurred in four patients, followed by empyema. The morbidity rate of the patients who underwent rethoracotomy due to BPF was $23.5 \%$.

The other indications for rethoracotomy were chylothorax, lobe torsion, parenchymal air leak and collapse, separation of the thoracotomy incision and diaphragmatic laceration. One patient, who had torsion in the lower lobe after left upper lobectomy, underwent completion pneumonectomy on the third postoperative day. Chylothorax was detected in a patient after right pneumonectomy due to bronchial carcinoma. As no decrease in chylous leak was observed despite all 
Table 5. Details of rethoracotomy due to parenchymal air leak and collapse

\begin{tabular}{|c|c|c|c|c|c|c|}
\hline Gender/Age (year) & First operation & $\begin{array}{l}\text { Day of } \\
\text { rethoracotomy }\end{array}$ & $\begin{array}{l}\text { Location of } \\
\text { air leak }\end{array}$ & Rethoracotomy & Predisposing factor & $\begin{array}{c}\text { Number of days } \\
\text { in hospital after } \\
\text { rethoracotomy }\end{array}$ \\
\hline Male/68 & $\begin{array}{l}\text { Right upper lobe } \\
\text { apical bullae } \\
\text { resection }\end{array}$ & 13 & $\begin{array}{l}\text { Lower lobe, } \\
\text { due to rib } \\
\text { fracture }\end{array}$ & $\begin{array}{l}\text { Rethoracotomy, } \\
\text { repair of } \\
\text { parenchyma, } \\
\text { rib resection }\end{array}$ & $\begin{array}{c}\text { Rib fracture } \\
\text { during thoracotomy, } \\
\text { emphysema }\end{array}$ & 6 \\
\hline Male/57 & $\begin{array}{l}\text { Right upper lobe } \\
\text { apical bullae } \\
\text { resection }\end{array}$ & 1 & $\begin{array}{c}\text { Stapler line, } \\
\text { apex of the lung }\end{array}$ & $\begin{array}{l}\text { Rethoracotomy, } \\
\text { repair of } \\
\text { parenchyma }\end{array}$ & $\begin{array}{l}\text { Technical causes } \\
\text { (Opening in the } \\
\text { stapler line) }\end{array}$ & 4 \\
\hline Male/39 & $\begin{array}{l}\text { Bilobectomy } \\
\text { superior }\end{array}$ & 9 & $\begin{array}{l}\text { Lower lobe, } \\
\text { due to rib } \\
\text { fracture }\end{array}$ & $\begin{array}{l}\text { Rethoracotomy, } \\
\text { repair of } \\
\text { parenchyma, } \\
\text { rib resection }\end{array}$ & $\begin{array}{c}\text { Rib fracture during } \\
\text { thoracotomy, } \\
\text { previous } \\
\text { tuberculosis }\end{array}$ & 7 \\
\hline Male/80 & $\begin{array}{l}\text { Left lower } \\
\text { lobectomy }\end{array}$ & 4 & $\begin{array}{l}\text { Upper lobe } \\
\text { apical bullae }\end{array}$ & $\begin{array}{c}\text { Rethoracotomy, } \\
\text { the resection of } \\
\text { apical bullae with } \\
\text { stapler }\end{array}$ & Bullous lung & Exitus \\
\hline
\end{tabular}

Table 6. Range of mortality and morbidity according to causes of rethoracotomy

\begin{tabular}{|c|c|c|c|c|c|c|}
\hline \multirow[t]{2}{*}{ Cause of rethoracotomy } & \multicolumn{2}{|c|}{ Number of patients } & \multicolumn{2}{|c|}{ Mortality } & \multicolumn{2}{|c|}{ Morbidity } \\
\hline & $\mathrm{n}$ & $\%$ & $\mathrm{n}$ & $\%$ & $\mathrm{n}$ & $\%$ \\
\hline Hemorrhage & 41 & 1.2 & 7 & 17.1 & 16 & 39 \\
\hline Bronchopleural fistula & 17 & 0.5 & 7 & 41.2 & 4 & 23.5 \\
\hline Other & 8 & 0.2 & 2 & 25 & 2 & 25 \\
\hline Total & 66 & & 16 & 24.2 & 22 & 33.3 \\
\hline
\end{tabular}

conservative treatment, rethoracotomy was performed and thoracic duct was ligated. Due to parenchymal air leak and collapse, early rethoracotomy was performed on one patient and late rethoracotomy on three patients. In two of three patients with late rethoracotomy, as a result of rib fracture during thoracotomy, parenchymal air leak was detected. The details about parenchymal air leak and collapse may be found in Table 5 .

The postoperative morbidity and mortality rates were $33.3 \%(n=22)$ and $24.2 \%(n=16)$, respectively (Table 6). The postoperative mortality rate after rethoracotomy was $28.3 \%$ (15/53) in the patients who underwent surgery due to malignant disease and $7.7 \%$ $(1 / 13)$ in the patients with benign pathologies.

\section{DISCUSSION}

Although video-assisted thoracoscopic surgery (VATS) has been often used and thoracic surgical procedures have shifted to minimally invasive approach since the early 1990s, there has been almost no significant reduction in the rate of early rethoracotomy. ${ }^{[3]}$ Furthermore, the mortality rates following rethoracotomy are still high. ${ }^{[7]}$ In this study, initial indication of surgery in 15 of 16 patients with postoperative mortality following rethoracotomy was non-small cell lung cancer (NSCLC). For this reason, it can be said that postoperative mortality is much higher particularly in patients with malignant disease than in patients having benign pathologies (28.3\% vs. $7.7 \%)$.

The rate of rethoracotomies performed due to early complications was $2 \%$. This rate was worthwhile due to the large number of patients. While the rates of thoracotomy due to early complications following VATS are lower, this rate gets higher after thoracotomy. In a current study, the rate for VATS was reported as $0.6 \%$, whereas the rate for thoracotomy was $1.4 \%$ in patients requiring early reexploration. ${ }^{[8]}$

Hemorrhage following thoracic surgery is rarely seen but it is still the most common cause of early rethoracotomy. ${ }^{[2,3,5,8]}$ Rethoracotomy rate due to hemorrhage is between $0.5 \%$ and $2.7 \% .^{[1-3,6,7-9]}$ In this study, the rate of rethoracotomy due to hemorrhage was $1.2 \%(n=40)$ and 38 patients were in the early rethoracotomy group. The other three patients in the late rethoracotomy group were patients who had 
clotted hemothorax, rather than an active bleeding. In some patients, postoperative bleeding may not affect hemodynamic stability but a clotted hemothorax may be detected in radiological examination. These patients have an indication for rethoracotomy to prevent trapped lung or empyema. The patients in whom any focus of bleeding could not be found and who underwent surgery due to clotted hemothorax constitute $36.6 \%$ of the hemorrhage group.

The most common focus of bleeding are the thoracic wall due to inadequate hemostasis, intercostal vein and rarely other veins. ${ }^{[10-12]}$ Patients using antiplatelet agents such as aspirin and clopidogrel, as well as warfarin, antidepressants and antipsychotics which prolong bleeding time, medicines containing ginseng or herbal products in preoperative period should be well evaluated. Particularly the use of herbal medicines is more common than expected and their effects on thoracic surgery are unknown; therefore, such drugs should be stopped at least two weeks before lung resection. ${ }^{[13]}$ Eight of 41 patients included in this study were using antiaggregant drugs (19.5\%). These patients using aspirin or clopidogrel due to coronary artery disease stopped using these drugs at least five days before the surgery. Seven of these eight patients underwent lung resection due to NSCLC and four patients received neoadjuvant chemotherapy, as well. One patient had a history of herbal medicine. During rethoracotomy, it was observed that all of these patients had mild bleeding from the chest wall or mediastinal adipose tissue. This suggests that discontinuation of antiaggregant drugs, neoadjuvant therapy or herbal medicines five days before the surgery may not completely remove the risk of hemorrhage. The most common approach is that use of clopidogrel should be stopped five days before the operation and that low-dose aspirin does not need to be discontinued. ${ }^{[14]}$ However, it is known that antithrombotic activity of clopidogrel lasts for three to 10 days after the drug is discontinued and that activity of aspirin, in fact, lasts up to seven days. Many surgical procedures can be performed with low risk of hemorrhage on aspirin. Nevertheless, thoracic surgical procedures should be excluded from this group. In particular, in cases where there is a multiple risk of hemorrhage, a period of 7-10 days may be recommended instead of five days after the discontinuation of the drugs. It should be remembered that hemorrhage can occur even if these drugs are discontinued before surgery. The cardiologist and the anesthetist must participate in the discussion of terminating these drugs as well as the surgeon. The risk/ benefit ratio of the patients with predisposing risk factors such as neoadjuvant therapy for hemorrhage should be assessed. In these mixed groups of patients with high risk of bleeding, clinical studies on the perioperative drug use are needed in order to perform the major surgical operations safely.

Rib fractures during thoracotomy increase postoperative morbidity. This can be more common particularly in the elderly patients. Fractured ribs can cause air leak as a result of parenchymal injury, hemorrhage and thoracotomy pain. For this reason, some thoracic surgeons cut the lower rib in the thoracotomy line from the posterior part, particularly in elderly patients and remove the risk of segmental fracture before placing the retractor. ${ }^{[15]}$ Not only does this provide a better surgical exposure but also avoids the complications that may arise due to an unintentional fracture. The possibility of rib fracture is higher in muscle-protecting thoracotomies. ${ }^{[16]}$ Among the rethoracotomies performed in our department, rib fracture was present in eight patients. All of these patients were over the age of 60 and underwent serratus anterior muscle-protecting thoracotomy. Rethoracotomy was performed on six patients due to hemorrhage and on two patients due to pulmonary parenchymal injury and prolonged air leak associated with the rib fracture. It is important to show utmost care during thoracotomy, to open the thoracic retractor in a controlled manner by stretching the ribs and to place the retractor by getting support from the bottom of scapula. If a better surgical exposure is desired, thoracotomy should be performed by cutting the ribs from the posterior part or removing a rib.

In a series in which patients with immediate rethoracotomy due to hemorrhage were analyzed, the rate of rethoracotomy was $2.6 \%$ and the mortality rate was $22.5 \%{ }^{[1]}$ In addition, in an aforementioned study, it was stated that the rate of mortality due to postoperative hemorrhage is significantly higher than the rate of mortality due to intraoperative hemorrhage. ${ }^{[1]}$ In another study, the rate of rethoracotomy due to hemorrhage was $2.7 \%$ and the rate of mortality was $3.3 \% .{ }^{[9]}$ In our study, the mortality of rethoracotomies due to hemorrhage was found to be $17 \%$ and it is in the range reported in the former articles related to this topic.

The rate of postoperative early rethoracotomy due to BPF was between $0.1 \%$ and $0.7 \%$ in several studies..$^{[2,3,6-8]}$ In our analysis, the rate of rethoracotomy due to BPF was $0.5 \%$. Only two patients underwent early rethoracotomy in the first 72 hours, considering technical insufficiency. Completion pneumonectomy was performed on one of these patients and resulted in postoperative mortality. A further resection was needed for fistula treatment in three of the other 
15 patients who underwent late rethoracotomy due to BPF. Completion pneumonectomy was performed on one of the aforesaid patients but this also resulted unfortunately in mortality. Of two patients who underwent middle lobectomy and bronchial sleeve resection, one ended up with mortality and the other was discharged without complication. Most of the further resections performed due to BPF treatment resulted in mortality. The majority of the patients who underwent rethoracotomy due to BPF were active smokers and had right-sided procedures. According to the analysis of predisposing factors for fistula, at least one of neoadjuvant therapy, diabetes and previous tuberculosis was found in $58.8 \%$ (10/17) of the patients. Six of 13 patients who underwent only stump revision or additional supplemental procedures to stump by intercostal muscle flap, omentum transposition and/or autologous fibrin glue were discharged without complication, whereas BPF developed again in three patients and postoperative mortality was seen in four patients.

Of seven patients who underwent rethoracotomy due to BPF and ended up with postoperative mortality, two patients died due to massive hemoptysis, while the causes of mortality in five patients were recurrence of BPF and respiratory failure. In our study, the mortality rate in the patients with rethoracotomy due to BPF was $41.2 \%$ and the morbidity was $23.5 \%$. In another study in which 13 patients underwent rethoracotomy due to $\mathrm{BPF}$, the mortality rate was $38.4 \% .^{[2]}$ These results show clearly the high morbidity and mortality rates of rethoracotomy following BPF; therefore, especially in right pneumonectomy cases, it is important to show great attention to patients with a history of diabetes and tuberculosis or neoadjuvant therapy in order to avoid BPF. Every effort should be made to eliminate the risk factors that may cause BPF. Infection must be treated and nutritional status must be optimized before surgery. No clamps or cautery should be used when dividing the bronchus. The bronchial stump should be closed with the smallest size absorbable suture material and the suture tension should be kept as low as possible. The stump must be covered by a viable flap particularly in risky patients. The presence of hematoma prevents the healing of the stump and is a risk factor for BPF, so care must be taken for appropriate hemostasis. ${ }^{[17]}$

Bronchopleural fistula treatment depends on a number of factors including the underlying etiology, the size and the features of the fistula, time of onset of the postoperative fistula and condition of the patient. Surgery is the suitable treatment of choice in this situation but endoscopic techniques are also an alternative method when surgery is not possible or has to be postponed. ${ }^{[18]} \mathrm{A}$ number of endoscopic procedures have been described to close BPF, including the application of different materials (fibrin glues, demineralized human donor spongiosa, metallic or silicone stent and sclerosant agents); however, none of them has been found to be the ideal option. ${ }^{[19]}$ Some authors have previously reported that the successful treatment of BPFs with a size not exceeding $5 \mathrm{~mm}$ is using minimally invasive techniques. ${ }^{[19]}$ However, in the case of larger fistulas, open surgery is often needed. Additionally, new endobronchial closure techniques for larger fistulas are remarkable. There are studies saying that conical self-expandable nitinol stents can be a solution to fistulas larger than $5 \mathrm{~mm} \cdot{ }^{[19,20]}$ They state that this method enables acute respiratory failure to be overcome and the patient to be prepared for another surgical procedure to close the fistula such as omentoplasty which is a satisfactory technique. ${ }^{[20]}$

Another cause of rethoracotomy is lobar torsion. Middle lobe torsion is more common, particularly after upper lobectomy. Wagner and Nesbitt ${ }^{[21]}$ reported that $70 \%$ of lobar torsions develop following right upper lobectomy and $15 \%$ following left upper lobectomy. The mechanism of lobar torsion is based on incision of pulmonary ligament, complete separation of the middle lobe from the next lobe, nonventilated lobe, pleural effusion and absence of pleural adhesions. Detorsion should be performed via rethoracotomy within a few hours after lobe torsion. Otherwise, the lobe will necessarily be resected due to gangrene. Our patient thus underwent rethoracotomy on the fourth day due to lower lob torsion and gangrene following left upper lobectomy and completion pneumonectomy was performed.

While rethoracotomy is considered obligatory for severe bleeding, early BPF or lobar torsion, some indications such as prolonged air leak or chylothorax are questionable. When four patients who underwent rethoracotomy due to prolonged air leak were examined, it was found out that the main causes of air leak were technical insufficiencies in the stapler line, bullae rupture or rib fractures during thoracotomy. In the case of technical insufficiency in the stapler line for prolonged air leak, the patient immediately underwent rethoracotomy on the first day, whereas other patients received conservative treatment for a few days. Rethoracotomy due to chylothorax was needed for one patient $(0.03 \%)$. Conservative treatment methods were used in this patient; however, since the chylous leak did not stop, rethoracotomy was performed on the $12^{\text {th }}$ day. The rate of early rethoracotomy for 
Table 7. Previously reported rethoracotomy and mortality rates

\begin{tabular}{|c|c|c|c|c|c|c|c|c|c|}
\hline & \multirow[t]{2}{*}{ Operative approach } & \multirow[t]{2}{*}{$\begin{array}{l}\text { Overall } \\
\text { number of } \\
\text { patients }\end{array}$} & \multicolumn{2}{|c|}{$\begin{array}{l}\text { Number and rate of } \\
\text { rethoracotomy }\end{array}$} & \multicolumn{2}{|c|}{$\begin{array}{l}\text { Number and rate of } \\
\text { rethoracotomy } \\
\text { due to hemorrhage }\end{array}$} & \multicolumn{2}{|c|}{$\begin{array}{l}\text { Number and rate of } \\
\text { rethoracotomy } \\
\text { due to BPF }\end{array}$} & \multirow{2}{*}{$\begin{array}{c}\begin{array}{c}\text { Mortality } \\
\text { rate }\end{array} \\
\%\end{array}$} \\
\hline & & & $\mathrm{n}$ & $\%$ & $\mathrm{n}$ & $\%$ & $\mathrm{n}$ & $\%$ & \\
\hline Sirbu et al. ${ }^{[2]}$ & Thoracotomy & 1960 & 73 & 3.7 & 38 & 1.9 & 13 & 0.7 & 17.8 \\
\hline Parshin et al. ${ }^{[6]}$ & NA & 14962 & 223 & 1.5 & 168 & 1.1 & 57 & 0.4 & NA \\
\hline Plaksin et al. ${ }^{[7]}$ & NA & 2615 & 34 & 1.3 & 14 & 0.5 & 7 & 0.3 & 37.5 \\
\hline Foroulis et al. ${ }^{[3]}$ & VATS/thoracotomy & 719 & 33 & 4.6 & 9 & 1.2 & 4 & 0.5 & 6.1 \\
\hline Yang et al. ${ }^{[8]}$ & VATS/thoracotomy & 19304 & 195 & 1.01 & 143 & 0.7 & 22 & 0.1 & 5.13 \\
\hline Our study 2018 & Thoracotomy & 3292 & 66 & 2 & 41 & 1.2 & 17 & 0.5 & 24.2 \\
\hline
\end{tabular}

BPF: Bronchopleural fistula; NA: Not available; VATS: Video-assisted thoracoscopic surgery.

chylothorax was reported to be between $0.05 \%$ and $0.3 \%$ in the literature. ${ }^{[3,8,22]}$

Separation of the thoracotomy incision which needs rethoracotomy is very rare. ${ }^{[3]}$ In this study, only one patient $(0.03 \%)$ required revision by rethoracotomy. This patient underwent lobectomy via right thoracotomy due to NSCLC; however, on the $17^{\text {th }}$ day, the patient underwent revision via rethoracotomy after wound infection.

The rethoracotomy rate of $2 \%$ in our study is in the range of $1 \%-4.6 \%$, which was mentioned in other series. ${ }^{[2-8]}$ The rate of mortality following rethoracotomy was $24.2 \%$ and the morbidity rate was $33.3 \%$. The analysis of rethoracotomy and mortality rates in several different studies is shown in Table 7. Considering the fact that 16 of 66 patients who underwent rethoracotomy ended up with death and that 22 patients had serious complications, it can be said that the time course for more than half of the patients was negative.

Our study has some limitations. First, it was a retrospective and single-centered study. Second, there were several different surgical teams performing the surgeries. Finally, we could not question the use of herbal medicines in all patients who underwent retoracotomy for bleeding.

In conclusion, morbidity and mortality rates are high particularly for patients who underwent rethoracotomy due to bronchopleural fistula and hemorrhage. The rib fractures during thoracotomy and antiaggregant drugs are noteworthy for hemorrhage. In fact, rethoracotomy is lifesaving in most of the occasions following major thoracic surgery. Our study nevertheless provides strong evidence for the fact that rethoracotomy increases morbidity and mortality, particularly with additional further resection.

\section{Declaration of conflicting interests}

The authors declared no conflicts of interest with respect to the authorship and/or publication of this article.

\section{Funding}

The authors received no financial support for the research and/or authorship of this article.

\section{REFERENCES}

1. Péterffy A, Henze A. Haemorrhagic complications during pulmonary resection. A retrospective review of 1428 resections with 113 haemorrhagic episodes. Scand J Thorac Cardiovasc Surg 1983;17:283-7.

2. Sirbu H, Busch T, Aleksic I, Lotfi S, Ruschewski W, Dalichau H. Chest re-exploration for complications after lung surgery. Thorac Cardiovasc Surg 1999;47:73-6.

3. Foroulis CN, Kleontas A, Karatzopoulos A, Nana C, Tagarakis $\mathrm{G}$, Tossios P, et al. Early reoperation performed for the management of complications in patients undergoing general thoracic surgical procedures. J Thorac Dis 2014;6:21-31.

4. Van't Westeinde SC, Horeweg N, De Leyn P, Groen HJ, Lammers JW, Weenink C, et al. Complications following lung surgery in the Dutch-Belgian randomized lung cancer screening trial. Eur J Cardiothorac Surg 2012;42:420-9.

5. Pálffy G, Forrai I, Csekeö A, Kulka F. Analysis of reoperations after 10,000 lung resections. Zentralbl Chir 1984;109:72-80. [Abstract]

6. Parshin VD, Biriukov IuV, Gudovskii AM, Grigor'eva SP. Rethoracotomy in thoracic surgery. Khirurgiia (Mosk) 2012;5:4-9. [Abstract]

7. Plaksin SA, Petrov ME. Early rethoracotomies for diseases and chest traumas. Vestn Khir Im I I Grek 2012;171:20-3. [Abstract]

8. Yang Y, Gao W, Zhao H, Yang Y, Shi J, Sun Y, et al. Risk factors and consequences of perioperative reoperation in patients undergoing pulmonary resection surgery. Surgery 2016;159:591-601.

9. Ermolov AS, Stonogin VD. Rethoracotomy because of hemorrhage in the early postoperative period after operations on the lungs and mediastinal organs. Vestn Khir Im I I Grek 1996;155:67-70. [Abstract] 
10. Milano MJ. Indications for reexploration thoracotomy. Current topics in general thoracic surgery: an international series. In: Peters RM, Toledo J, editors. Perioperative care: Current Topics in General Thoracic Surgery. Vol 2. 1st ed. Amsterdam: Elsevier 1992. p. 315-24.

11. Péterffy A, Henze A. Haemorrhagic complications during pulmonary resection. A retrospective review of 1428 resections with 113 haemorrhagic episodes. Scand J Thorac Cardiovasc Surg 1983;17:283-7.

12. Uramoto H, Shimokawa H, Tanaka F. Postoperative bleeding after surgery in patients with lung cancer. Anticancer Res 2014;34:981-4.

13. Litle VR, Swanson SJ. Postoperative bleeding: coagulopathy, bleeding, hemothorax. Thorac Surg Clin 2006;16:203-7.

14. Hamm CW, Bassand JP, Agewall S, Bax J, Boersma E, Bueno H, et al. ESC Guidelines for the management of acute coronary syndromes in patients presenting without persistent ST-segment elevation: The Task Force for the management of acute coronary syndromes (ACS) in patients presenting without persistent ST-segment elevation of the European Society of Cardiology (ESC). Eur Heart J 2011;32:2999-3054.

15. Deslauriers J, Mehran RJ. Posterolateral thoracotomy. Oper Tech Thorac Cardiovasc Surg 2003;8:51-7.
16. Normandin L, Pagé A, Verdant A. Thoracotomy with muscle sparing. Ann Chir 1991;45:760-3. [Abstract]

17. Yazgan S, Gürsoy S, Yoldaş B, Üçvet A, Usluer O. Bronchopleural fistulas: a challenging complication, results of 50 patients. Turk Gogus Kalp Dama 2016;24:697-702.

18. Lois M, Noppen M. Bronchopleural fistulas: an overview of the problem with special focus on endoscopic management. Chest 2005;128:3955-65.

19. Andreetti C, D'Andrilli A, Ibrahim M, Ciccone AM, Maurizi G, Mattia A, et al. Effective treatment of post-pneumonectomy bronchopleural fistula by conical fully covered self-expandable stent. Interact Cardiovasc Thorac Surg 2012;14:420-3.

20. Dutau H, Breen DP, Gomez C, Thomas PA, Vergnon JM. The integrated place of tracheobronchial stents in the multidisciplinary management of large post-pneumonectomy fistulas: our experience using a novel customised conical self-expandable metallic stent. Eur J Cardiothorac Surg 2011;39:185-9.

21. Wagner RB, Nesbitt JC. Pulmonary torsion and gangrene. Chest Surg North Am 1992;2:839-52.

22. Wakim R, Bellamy J, Irani M. Early reoperation in chylothorax after thoracic surgery. Ann Chir 1995;49:863-8. [Abstract] 